\title{
The quest for internationally recognized divisions of Cambrian time
}

1 Institut für Paläontologie, Bayrische Julius-Maximilians-Universität, Würzburg, Germany. E-mail < palo001@ rzroe.uni-wuerzburg.de >. 2 La Freunie, 19510 Masseret, France. E-mail<shergold@internet19.fr >.

Although regional stadial schemes are available, and widely used, on all the major Cambrian continents, Armorica, Australia, Avalonia, Baltica, China, Kazakh -stania, Laurentia, Siberia, the system currently has no formally agreed internationally recognized divisions. Since the IUGS Commission on Stratigraphy requires the definition of Global Boundary Stratotype Sections and Points (GSSPS), it has become the prime objective of the International Subcommission on Cambrian Stratigraphy to commence to document suitable biostratigraphic horizons within the system which might assist in achieving this goal. In this paper we suggest the consideration of fourteen late Early Cambrian-terminal Cambrian levels, and document their stratigraphical and biogeographical distributions. Once agreement within the Subcommission is reached on which are the most suitable, it will be necessary to search for appropriate stratotype sections, bearing in mind the necessity to calibrate the biostratigraphy by way of non-biological correlation techniques, such as chemostratigraphy and magnetostratigraphy.

\section{Introduction}

The Cambrian and Carboniferous Systems are the only major periods of the Phanerozoic which are presently without formal international stages and series. In the case of the Cambrian this remarkable situation is partly due to the strong regional aspects of studies over prolonged periods of time, and partly a result of subsequent changes in the stratigraphic position of the lower boundary of the Cambrian. Cambrian stratigraphical units primarily satisfied requirements regionally rather than globally and, as a result, often developed into parochial subdivisions. As emphasized by the International Subcommission on Cambrian Stratigraphy (ISCS), the growing international interest during the last decade has led to an increasing number of projects, mainly focussing on the lower and upper boundaries of the system. Accordingly, regional correlation charts still suffer from the absence of a formally agreed left-hand scale. The recognition of formal international stages or series for the Cambrian has thus developed into the major task of Cambrian stratigraphers.

The last decades of research on Cambrian stratigraphy were characterized mainly by the long struggle for defining the lower and upper boundaries of the Cambrian. The first was finally decided in 1991 (Landing, 1991), and the last is presently close to a final decision (Cooper, 1998; Cooper and Nowlan, 1999). Internal Cambrian divisions, however, have been extensively discussed for some Cambrian continents but rarely in a global context. The most prominent exceptions are articles by Robison and Rowell (1976), Robison et al. (1977) and Rowell et al. (1982) who examined possible stage boundaries in the light of the knowledge of two decades ago. This article reviews and examines the possibilities for Cambrian divisions on the basis of more recent information (Figure 1) and shows that the faunal horizons with potential for international correlation emphasized by Robison et al. (1977) are still among the most powerful levels with potential for defining the lower boundaries of international stages.

\section{Traditional Cambrian series}

The traditional subdivision of the Cambrian System is based on the comforting and archetypical tripartition which characterizes most of the other periods of earth's history. However, other than for the classical Triassic or Jurassic, the tripartition of the Cambrian is an awkward and largely artificial subdivision. The resulting LowerMiddle and Middle-Upper Cambrian series boundaries are located at stratigraphic levels that are difficult to define on a global scale by biostratigraphic or physical methods and/or bear major problems of correlation. Especially, the Lower-Middle Cambrian boundary has been the topic of intensive research in recent years and shown to be at different chronostratigraphic levels in the various regions (Geyer,

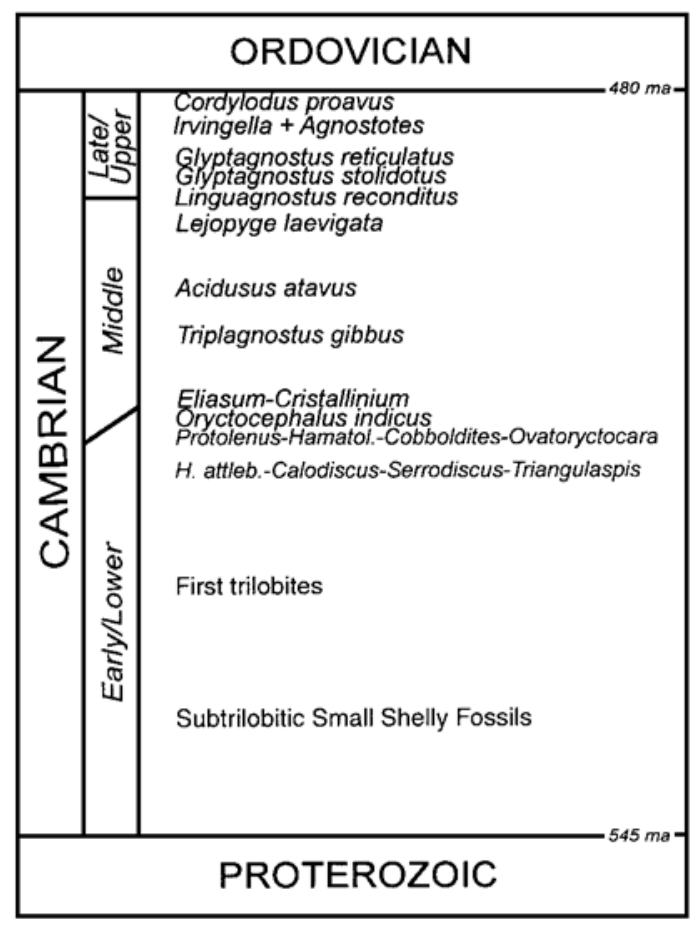

Figure 1 Generalized stratigraphic position of the reviewed horizons of possible Cambrian divisions with potential for international correlation. 
1990, 1998; Geyer and Palmer, 1995; Zhuravlev, 1995). In addition, the lower boundary of the Cambrian System has been shifted downward so that the Early Cambrian now represents a period of time that is considerably longer than the Middle plus Upper Cambrian (Landing, 1996; Landing et al., 1998).

In the search for divisions of the Cambrian, the traditional series boundaries should not be regarded as holy shrines. Practical series primarily need internationally suitable boundaries that are somehow recognizable in the majority of the Cambrian regions rather than being recognizable in one or two areas. A tripartition of the revised Cambrian System would not only have consequences for possible confusion of traditional old and new Lower, Middle, and Upper Cambrian Series, but also lacks adequate positions for such revised stage boundaries. Thus, subdivision into four, five, or six series may be more appropriate. It could furnish established divisions as well as offering the possibility of establishing boundaries at well correlatable levels. Such possible levels are discussed in the following paragraphs in stratigraphically descending order.

\section{Base of the Cordylodus proavus Zone (C.p.)}

Cordylodus proavus has a cosmopolitan distribution (An, 1981; Miller, 1984), having been described from Argentina (Jujuy Province), Australia (Georgina and Bonaparte Basins), Canada (North West Territories, Alberta, New Brunswick, Newfoundland), China (Anhui, Hebei, Hubei, Hunan, Jilin, Liaoning, Shandong, Shanxi, Zhejiang), Greenland, Iran, Kazakhstan, Mexico, the Siberian Platform, the East European Platform (northern Estonia, St. Petersburg area) and Sweden, Turkey, USA (Arkansas, Idaho, Maryland, Missouri, Nevada, New Jersey, New York, Oklahoma, Pennsylvania, South Dakota, Texas, Utah, Vermont, Wisconsin), and Wales. In carbonate platform biofacies, it has been used biostratigraphically to define the base of the Ibexian Stage in Laurentia, the Datsonian Stage in Australia, the Xinchangian Stage in China and the Ungurian Stage in Kazakhstan. In Laurentia, the first appearence datum (FAD) of C. proavus marks the base of the Symphysurinid biomere. Cordylodus proavus, however, has a long stratigraphic range, almost to the Cambrian-Ordovician boundary, as currently recognized by the International Cambrian-Ordovician Boundary Working Group, and its range is not necessarily homotaxial in all the regions listed above. Its FAD coincides with conodonts of the Hirsutodontus hirsutus Subzone immediately succeeding those of the Cambrooistodus minutus Subzone of the Eoconodontus Zone, at a time of significant faunal turnover. On the trilobite biostratigraphic scale the base of the Cordylodus proavus Zone correlates with the Eurekia apopsis Subzone of the Saukia Zone in Laurentia.

\section{Irvingella in association with Agnostotes (I.-A.)}

These genera have overlapping ranges in the medial part of the Late Cambrian, and quite extensive palaeogeographic distributions. Irvingella occurs in Australia (western Queensland), Vietnam, China (Hunan, Liaoning, Anhui, Xinjiang), South Korea, Kazakhstan (Lesser Karatau), Russia (NE Siberian Platform, NW Siberian Platform, Novaya Zemlya), Sweden, UK, Canada (Alberta, British Columbia, North West Territories), and USA (Oklahoma, Missouri, Montana, Nevada, Texas, Utah, Wisconsin, Wyoming), Argentina, and possibly in Antarctica (Northern Victoria Land). Reported occurrences of Irvingella from Nei Monggol need confirmation. In Laurentia it ranges across the Steptoean-Sunwaptan Stage boundary; in Australia it defines the beginning of the Iverian Stage; in China it occurs in the middle and late Changshanian; and in Kazakhstan and Siberia, the late Sakian. Agnostotes (embracing its synonyms Pseudoglyptagnostus $\mathrm{Lu}$ in Wang, 1964 and Glyptagnostotes Lazarenko, 1966) occurs in Australia (western Queensland, Tasmania?), Canada (British Columbia, North West Territories), China (Hunan, Liaoning, Nei Monggol, Qinghai, Xinjiang, Zhejiang), Kazakhstan (Lesser Karatau), Russia (NE Siberian Platform), South Korea, and possibly USA (Nevada?) according to Pratt (1992). The FAD of Agnostotes is apparently earliest in Canada and its youngest occurrence is in Nei Monggol. In a significant number of regions Irvingella and Agnostotes co-occur and have been used as zonal index fossils: Irvingella tropica-Agnostotes inconstans Zone in Australia; I. angustilimbata-A. latilimbata Zone in South China (Hunan); I. tropica-A. clavata in the Irvingella-Sinoproceratopyge kiangshanensis Zone in the Tarim Basin of NW China; I. major-A. elegans in the Irvingella-Cedarellus felix Zone of Yakutia; I. tropica-A. elegans in the Pseudagnostus "curtare" Zone of Kazakhstan; and I. major-A. clavata in the I. major Zone (marking the base of the Sunwaptan, following Chatterton and Ludvigsen, 1998) in Canada. The occurrence of the oldest species of the Irvingella clade (Palmer, 1965) with species of Agnostotes seems most useful biostratigraphically.

\section{Base of Glyptagnostus reticulatus Zone (G.r.)}

The Glyptagnostus reticulatus Zone is one of the most widely recognizable trilobite horizons. To be precise, the base of the range of G. reticulatus is eminently suitable to mark a stage and series boundary on a global scale as first discussed by Kobayashi (1949) and subsequently by Palmer (1962), Öpik (1966), Rosova (1968), and Robison et al. (1977). Its index fossil, Glyptagnostus reticulatus, has been identified from Antarctica (Ellsworth Mountains), Australia (western Queensland, Tasmania), Canada (British Columbia, North West Territories), China (S. Anhui, NW Gansu, E. Guizhou, W. Hunan, Xinjiang, W. Zhejiang), Denmark, Kazakhstan (Lesser Karatau), Norway, Russia (NW Siberian Platform, NE Siberian Platform), South Korea, Sweden, UK, USA (Alabama, Alaska, Nevada, Tennessee, Texas), and Argentina. It is used as a zonal index fossil in Siberia, Kazakhstan, the Yangtze Platform, Australia, and Laurentia. Co-occurrences with numerous other trilobites permit correlation into other regions such as Argentina and Baltica. The base of the zone marks the time of a significant faunal change that is expressed by the boundary between the Marjumiid and the Pterocephaliid biomeres in Laurentia (base of the Aphelaspis Assemblage-Zone), the base of the Idamean Stage in Australia, the base of the Sakian Stage in Kazakhstan (which is regarded there as the base of the Late Cambrian Series), the base of the Kugorian Stage in Siberia, and coincides with the base of the Olenus Stage and the base of the Homagnostus obesus Zone in Scandinavia (in the sense of Henningsmoen, 1957).

\section{Base of Glyptagnostus stolidotus Zone (G.s.)}

Glyptagnostus stolidotus has a similar but slightly less frequent occurrence to that of Glyptagnostus reticulatus. It is known from such regions as Antarctica (North Victoria Land), Australia (western Queensland, Northern Territory), China (E. Guizhou, W. Hunan, Xinjiang, W. Zhejiang), Kazakhstan (Lesser Karatau), Russia (NE Siberian Platform, Altay Sayan) and USA (Alabama). It is used as a formal index fossil in Siberia, Kazakhstan (late Ayusokkanian), the Yangtze Platform (late Kushanian), and Australia (late Mindyallan).

Table 1 Correlation chart for the Cambrian biostratigraphic units of important regions/paleocontinents. The South China column shows the newly intruduced stratigraphic scheme by Peng Shanchi, Zhou Zhiyi, Lin Tianrui, and Yuan Jinliang, approved by the Chinese National Committee on Stratigraphy, May 2000. Horizontal lines show positions of potential subdivisions as discussed in the text. Abbreviations: FT, first occurrence of trilobites; HCST, Hebediscus attleborensis-Calodiscus-Serrodiscus-Triangulaspis band; PHCO, Protolenus-Hamatolenus-Cobboldites-Ovatoryctocara band; O.i., Oryctocephalus indicus; T.g., Ptychagnostus gibbus; A.a., Acidusus atavus; P.p., Ptychagnostus punctuosus; L.l., Lejopyge laevigata; L.r., Linguagnostus reconditus: G.s., Glyptagnostus stolidotus; G.r., Glyptagnostus reticulatus; I.-A., Irvingella in association with Agnostotes; C.p., Cordylodus proavus. Generated for the International Subcommission of Cambrian Stratigraphy by G. Geyer, S. Peng, and J. H. Shergold (See pages 190-191). 


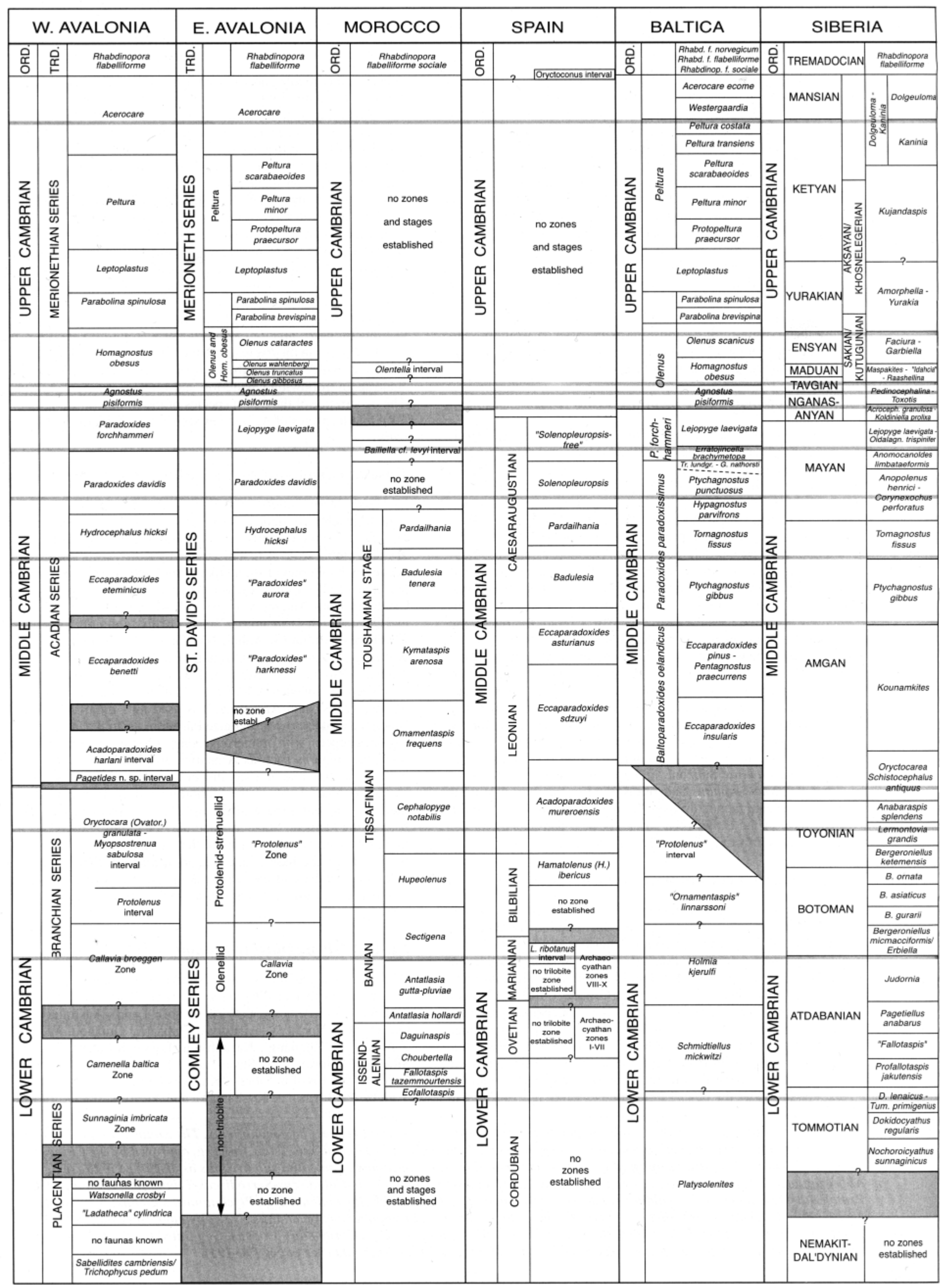

Episodes, v.23, no.3. 


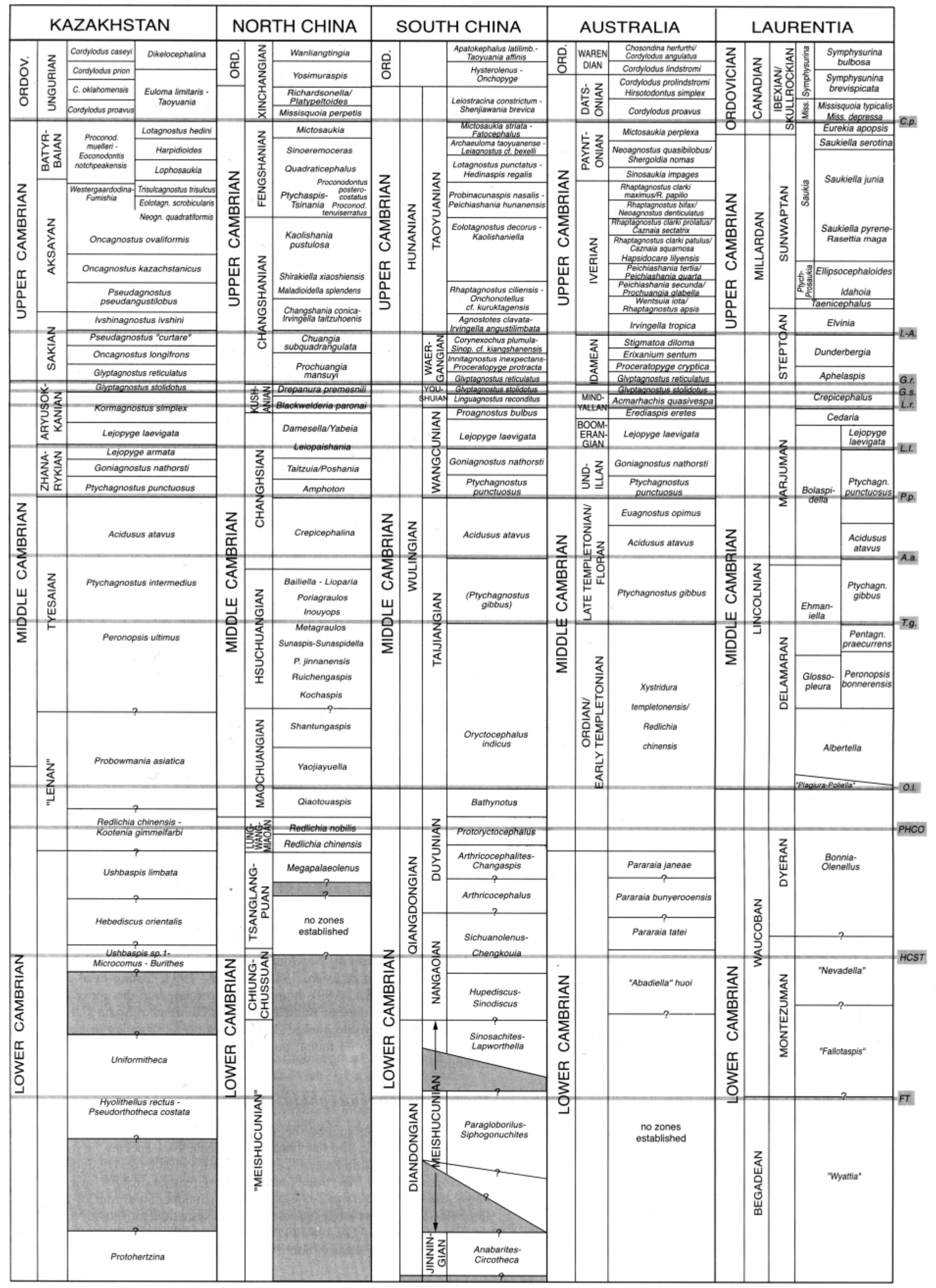


It directly underlies the zone of Glyptagnostus reticulatus and thus has a slightly less advantageous potential position for a stage or series boundary in traditionally Upper Cambrian strata.

\section{Base of the Linguagnostus reconditus Zone (L.r.)}

The traditional index fossil of the base of the Upper Cambrian is Agnostus pisiformis, which, in contrast to earlier reports, appears to be restricted to Sweden, Norway, Poland, England, Novaya Zemlya, and southeastern Newfoundland (e.g., Henningsmoen, 1958; Rushton, 1978). In addition, the Agnostus pisiformis Zone is seemingly based on local abundance, and A. pisiformis is present in the subjacent Lejopyge laevigata Zone (see Westergård, 1946, figs. 10-14; Peng and Robison, 2000). To overcome this problem, Peng and Robison (2000) suggest to use the lowest appearance of Linguagnostus reconditus to replace the Agnostus pisiformis level.

Linguagnostus reconditus, as emended by Peng and Robison (in press), is a distinctive and widespread species, known from South China, Australia, the Altay-Sayan region, England, and Scandinavia (e.g., Poletaeva and Romanenko, 1970; Taylor and Rushton, 1972; Rushton, 1978; Shergold et al., 1990; Ahlberg and Ahlgren, 1996; see synonymy in Peng and Robison, 2000). It can be used to define a brief zone with a number of species (Ammagnostus sinensis, Clavagnostus spinosus, and Pseudagnostus koerferi) restricted to this zone and a large number of additional species ranging into the zone (such as Acmarhachis typicalis, Kormagnostus minutus, Proagnostus bulbus, Glyptagnostus stolidotus, Hypagnostus brevifrons, and Tomagnostella sulcifera) (data from Peng and Robison, 2000).

The Linguagnostus reconditus Zone apparently correlates with much, or all, of Westergård's $(1922,1946)$ Agnostus pisiformis Zone of Scandinavia, and a global stage or series boundary at the base of this zone therefore would have the advantage of being as close as possible to the traditional Middle-Upper Cambrian boundary. However, Linguagnostus reconditus was previously widely neglected, or attributed to other species (see Peng and Robison, in press), and its FAD is not currently in use for any widely recognized stage.

\section{Base of Lejopyge laevigata Zone (L.l.)}

Although the areal occurrence of Lejopyge laevigata is a little more limited compared to some other late Middle Cambrian agnostoids, other trilobites and conodonts of the Lejopyge laevigata biota (e.g., the trilobites Opsidiscus bilobatus, Oidalagnostus trispinifer, Diplagnostus planicauda, Hypagnostus brevifrons, Megagnostus glandiformis, Peronopsis insignis, and the conodonts Gapparodus bisulcatus, Hertzina carinata, Prosagittodontus dahlmani), permit a relatively precise correlation into a number of other deeper water successions. Lejopyge laevigata occurs in Australia (western Queensland, Tasmania), China (Anhui, Guizhou, Hunan, Sichuan, Xinjiang, Zhejiang), Denmark, Germany (in erratics), Greenland, India (Ladakh), Kazakhstan (Lesser Karatau), Turkestan, Russia (southern Siberian Platform, NE Siberian Platform), Sweden, Norway, northern Poland, and USA (Alaska, Nevada). In Scandinavia, Siberia, Australia, Kazakhstan and China it is in use as a formal index fossil (Lejopyge laevigata and Lejopyge laevigata-Aldanaspis truncata Zones), and it defines the base of the Boomerangian Stage in Australia and the Ayusokkanian Stage in Kazakhstan. It should be emphasized that Agnostus pisiformis, the traditional index fossil for the base of the Upper Cambrian in Baltica, has been reported from the Lejopyge laevigata-Aldanaspis truncata Zone in Siberia (although convincing species have not been illustrated). Furthermore, it should be noted that L. laevigata is commonly reported to co-occur with $L$. armata. However, careful studies of sections indicate that $L$. armata appears to occur earlier in Kazakhstan and China, whereas L. laevigata predates $L$. armata in Laurentia.

\section{Base of Ptychagnostus punctuosus Zone (P.p.)}

Ptychagnostus punctuosus is a frequent and widely distributed agnostoid. Representatives have been described from such areas as
Australia, New Zealand, South China (Hunan), NW China (Xinjiang), Kazakhstan, Siberian Platform, Sweden, Denmark, Norway, England, Wales, Greenland, Canada (western Newfoundland, New Brunswick) and the USA (New York, Utah, Nevada). In most areas of its occurrence the species is used as an index fossil and defines an interval-zone. It defines the base of the Undillan Stage in Australia, the base of the Zhanarykian Stage in Kazakhstan, and the base of the newly proposed Wangcunian of China (Peng et al., 1998). Ptychagnostus punctuosus sensu stricto has a FAD which appears to define a useful time-marker.

\section{Base of Acidusus atavus Zone (A.a.)}

Acidusus atavus is a widespread species known from Australia (western Queensland, South Australia), Vietnam, China (Hunan, Guizhou, Xinjiang, Zhejiang), North Korea, Russia (Siberian Platform), Sweden, Denmark, Norway, UK, Greenland, Canada (western Newfoundland) and USA (Nevada, Utah). The base of the zone marks a significant faunal change, defining the base of the Marjuman Stage boundary in Laurentia (Ludvigsen et al., 1985). The base of the Acidusus atavus Zone corresponds with the base of the Floran Stage in Australia (Öpik, 1967). The faunal change documented at the base of the A. atavus Zone is correlated in Laurentia with that at the base of the Bolaspidella Zone, but this is not a biomere boundary in the definition of Palmer (1981, 1998) and Sundberg (1994).

\section{Base of Ptychagnostus gibbus Zone (T.g.)}

Ptychagnostus (or Triplagnostus) gibbus is even more widespread than Acidusus atavus. It is known from Antarctica (in erratics), Australia (western Queensland), Kazakhstan, Russia (Siberian Platform), Poland, Sweden, Norway, UK, Greenland, Canada (Newfoundland), and USA (Nevada, New York, Utah), and it is widely used as an index fossil (Baltica, Siberian Platform, Yangtze Platform, Australia). The Ptychagnostus gibbus Zone is the basal zone of the Paradoxides paradoxissimus Stage in Scandinavia (Westergård, 1946).

\section{Base of the Eliasum-Cristallinium Assemblage Zone}

Studies of acritarch assemblages revealed a pronounced change from the Volkovia-Liepaina assemblage to the Eliasum-Cristallinium assemblage (Moczydlowska, 1999). Both are used in define formal acritarch assemblage zones regarded as Lower and Middle Cambrian in age, respectively. The base of the Eliasum-Cristallinium Assemblage Zone has recently been suggested to define the base of the Middle Cambrian on a global scale (Moczydlowska, 1999). The Eliasum-Cristallinium assemblage is represented by a wide array of such species as Eliasum llaniscum, Cristallinium cambriense, Timofeevia lancarae, T. phosphoritica, and Lophosphaeridium latviense. It can be traced between shelf areas of various Cambrian continents and is known from such areas as Poland, Sweden, Spain, Morocco, Wales and southeastern Newfoundland (Vanguestaine and Van Looy, 1983; Martin \& Dean, 1988; Palacios, 1993; Young et al., 1994; Moczydlowska, 1999). It appears to correlate into the uppermost "Protolenus Zone" of Baltica, the upper Bilbilian of Spain and the upper Protolenid-Strenuellid Zone of Wales, but appears to be fairly unaffected by the faunal provincialism which is seen in the trilobite assemblages.

\section{Base of the Oryctocephalus indicus Zone (O.i.)}

Recent investigations suggest that the FAD of Oryctocephalus indicus may be suitable for the base of a GSSP. This species, first described from the Spiti area of Kashmir (Reed, 1910; revised by Jell and Hughes, 1997), has been found in the Great Basin area just above the top of the Bonnia-Olenellus Zone (Sundberg and McCollum, 1997) and in the lower part of the Kaili Formation, attributed to the Oryctocephalus-Xingrenaspis Assemblage-zone, in Guizhou province, Yangtze Platform, South China (Zhao et al., 1996; Yuan et 
al., 1997; Sundberg et al., 2000). A recent article discusses the potential of this latter occurrence as a GSSP, particularly because Oryctocephalus indicus is associated with a number of other oryctocephalids in South China and Laurentia as well as apparently Pagetia prolata (Sundberg et al.,2000).

Bathynotus occurs at the top of the subjacent zones in both regions, which marks the top of the Lower Cambrian. In the Bathynotus-Nangaops Assemblage-zone of South China, Bathynotus occurs together with Redlichia, a "traditional" Lower Cambrian faunal element. If the species of Bathynotus turn out to be coeval, the occurrence of this genus would tentatively permit a correlation into Siberia and Australia. Further correlation of the Siberian Platform with southeastern Newfoundland and from there to Great Britain would provide the base for a broad international correlation.

However, precise correlation into the western and central sectors of Gondwana remain problematic, and additional data are needed to corroborate the reliability of the data from Laurentia and South China, and the occurrence of Oryctocephalus indicus in chronic low diverse faunas poses an additional problem.

\section{Base of the Protolenus-Hamatolenus-Cobboldites- Oryctocara band (PHCO)}

Variable assemblages with both eodiscoid and polymerid trilobite genera around what is traditionally considered the Lower-Middle Cambrian transitional beds are known particularly from Avalonia and Western Gondwana. They have some potential for long distance correlation, although a precise chronocorrelation remains difficult for a number of regions because a deficiency of detailed studies in this interval. Those trilobite taxa include Cobboldites spp., Bathydiscus spp., Protolenus (Protolenus) spp., Latoucheia (Latoucheia) spp., Hamatolenus spp., Acadoparadoxides/Eoparadoxides spp., Ovatoryctocara granulata, and Clavigellus spp., known from such regions as Canada (southeastern Newfoundland, New Brunswick), UK (northern Wales and the Welsh Borderlands), Poland (Holy Cross Mountains), Spain (lower Leonian Stage of the Cantabrian Mountains and the Iberian Chains), Morocco (Cephalopyge notabilis Zone of the Moroccan Atlas ranges), Turkey, and Siberia. Correlation of these assemblages has been dealt with in a number of recent publications (Geyer, 1990, 1998; Geyer and Palmer, 1995), and the (relatively minor) differences in fine-scale correlation indicate problems related to taxonomic concepts as recently discussed by Geyer (1998).

Assemblages of the Protolenus-Hamatolenus-CobbolditesOryctocara band occur in both Lower and Middle Cambrian beds, indicating problems with the traditional assignment of the LowerMiddle Cambrian boundary in different regions (Geyer, 1990; Geyer and Palmer, 1995). The traditional concepts of the Lower-Middle Cambrian boundary, separately developed for Baltica (Brögger, 1886) and Laurentia (Walcott, 1891), are not coeval. The first occurrences of Paradoxides $s$. $l$. and the extinction of olenelloids are each on different stratigraphic levels and differ from region to region (Geyer, 1990, 1993; Geyer and Palmer, 1995).

\section{Base of the Hebediscus attleborensis-Calodiscus- Serrodiscus-Triangulaspis band (HCST)}

Relatively widespread eodiscoid trilobites mark a band in the upper part of the traditional Early Cambrian. Characteristic species of this assemblage include Hebediscus attleborensis, Calodiscus schucherti, Calodiscus helena, Calodiscus lobatus (in strict sense), Serrodiscus bellimarginatus, Triangulaspis vigilans, and Triangulaspis annio (Fletcher, 1972; Robison et al., 1977; Geyer, 1990; Geyer and Palmer, 1995). Most of the species have relatively limited occurrences, but their ranges show some regional overlap and associated taxa permit a subglobal recognition, such as in Baltica (Sweden), Avalonia (southeastern Newfoundland, New Brunswick, Welsh Borderlands), Western Gondwana (Spain, Morocco), Siberia, the Altay-Sayan Mountains, and Kazakhstan. Such assemblages occur at the top of the Callavia broeggeri Zone in southeastern Newfoundland and the Callavia Zone in England, the Sectigena Zone in Morocco, the top of the Judomia and B. micmacciformis-Erbiella Zone in Siberia. The relatively limited occurrences reduce the possibility of a sharply defined lower boundary of this assemblage, and additional evaluation is required to allow a precise definition needed for an appropriate stage or series boundary.

\section{At the first occurrence of trilobites $(F T)$}

The first occurrence of trilobites certainly marks an important step in biotic development. However, correlation of this level is a priori difficult for two reasons. First, and logically, the first appearance of trilobites must be diachronous because trilobites originated in a certain region and progressive migration into other regions led not only to differences in the first appearance data (FAD) of trilobites but also to marked provincialism. The few genera and species which have some intercontinental distribution usually have such limited local stratigraphic ranges that their true biozones are poorly recognized (Palmer, 1998). Paleomagnetic investigations as well as chemostratigraphic investigations such as oxygen and carbon isotope studies (e.g., Brasier, 1993; Brasier et al., 1992, 1994) of the Early Cambrian offer data to explain this enigmatic pattern of semi-endemic faunas. Recent paleomagnetic data (Kirschvink et al., 1997) may explain such a pronounced provincialism in the light of unusual rapid plate movements during the early Cambrian.

In addition, the first trilobites appear in many regions in strata that immediately overlie unconformities, which supposedly represent extensive hiati. Most of these trilobite assemblages are found in facies that suggest nearshore deposition or deposition in an inner detritic belt, and those biofacies are again characterized by endemic polymerid trilobites. Other fossils associated with these assemblages, such as archaeocyaths, molluscs, hyoliths, hyolithelminths, and other small shelly fossils, also have limited occurrences or show strong limitations to certain biofacies types, and thus have limited potential for intercontinental correlation. These facts suggest that a series boundary at the first occurrence of trilobites will be inappropriate because it generally lacks the possibility of global biostratigraphic identification and correlation. Identification by means of physical methods is promising, but cannot yet be taken into consideration.

\section{Subtrilobitic Small Shelly Fossils}

Small Shelly Fossils from supposedly earliest Cambrian strata have been extensively studied during the last two decades in such regions as Siberia, South China, Australia, India, Iran, Spain, the Canadian Cordillera, western U.S.A., and Mexico. However, no agreement has been achieved about the possibilities of intercontinental correlation by means of such Small Shelly Fossils. Preliminary examination of mollusk faunas from the Lower-Middle boundary interval suggests some potential for correlation (Geyer, 1986) but careful investigation and additional data are needed to quantify these results. The same is valid for Small Shelly Fossil assemblages from sub-trilobitic Early Cambrian levels. Uncertainties and misconceptions as well as generic oversplitting of SSFs obscure their potential for interregional, and possibly intercontinental, correlation. Especially the diverse SSF assemblages from Siberia and the Yangtze Platform may be used to calibrate paucispecific occurrences from other regions. However, major taxonomic revisions and investigations on the dependency from facies are needed before their value for correlation can be estimated.

\section{The way ahead}

The International Subcommission of Cambrian Stratigraphy recognizes good potential for global chronocorrelation at certain stratigraphic levels within the Cambrian, whereas other parts of the Cam- 
brian (particularly in the Early Cambrian) are, for the moment, devoid of fossil assemblages or physical markers that readily permit a precise and more-or-less equidimensional subdivision of the Cambrian. In our opinion, the best levels for international correlation for the definition of international Middle and Late Cambrian stages and/or series are the FADs of Triplagnostus gibbus, Ptychagnostus punctuosus, Lejopyge laevigata, Glyptagnostus reticulatus, Irvingella-Agnostotes and Cordylodus proavus. The trilobite zones are selected because they belong in well documented biostratigraphic sequences, e.g., Triplagnostus gibbus is predated by Pentagnostus praecurrens and postdated by Acidusus atavus; Lejopyge laevigata is predated by Goniagnostus nathorsti and succeeded by Lejopyge sinensis and in the Glyptagnostus lineage; Glyptagnostus reticulatus is predated by G. stolidotus. In addition, Ptychagnostus punctuosus is predated by $P$. affinis, and the occurrence of Goniagnostus nathorsti correlates with the upper part of the Ptychagnostus punctuosus Zone.The co-occurrence of the early species of Irvingella, such as I. tropica, with species of Agnostotes in a number of regions emphasizes the potential for correlation and also indicates that the index species are postdated by younger species of Irvingella such as I. major and I. perfecta. In contrast, the conodont horizon of Cordylodus proavus suggested is at a major faunal turnover although C. proavus is part of the Proconodontus lineage (Miller, 1984). These suggestions are made in the search for practical solutions for the meaningful subdivision of the Cambrian System.

In order to make progress on the definition of GSSPs for Cambrian stages and series, it is now necessary to arrange a formal ballot of Voting Members of International Subcommission on Cambrian Stratigraphy to agree on which of the Middle and Late Cambrian data suggested above are mostly acceptable internationally. The accompanying Chart (Table 1) indicates levels of correlation, which can be achieved at each datum. International Early Cambrian stage nomenclature is likely to remain in abeyance for some time yet, but a start can certainly be made on the later half of the Cambrian. Having agreed, or otherwise, the appropriate biostratigraphic levels, it will then be the task of the ISCS to identify suitable sections in which to define GSSPs for stages. It is envisaged that a suite of sections at each selected datum will be submitted to the Voting Members for elimination by formal ballot. Following this, the choice of naming the stages internationally must be addressed. For example, should existing regional names be adopted internationally, or should they be renamed for this important exercise?

\section{Acknowledgments}

An earlier version of this report with the attached correlation chart was circulated among members of the International Subcommission on Cambrian Stratigraphy and merits from resulting criticism and suggestions. Particularly helpful were comments and suggestions by Peng Shanchi (Nanjing), M. Moczydlowska (Uppsala), L. Babcock (Columbus, OH), Zhu Maoyan (Nanjing), Luo Huilin (Kunming), A. Yu. Zhuravlev and A. Yu. Rozanov (both Moscow), L. M. McCollum (Cheney, WA), A. R. Palmer (Boulder), F. A. Sundberg (Washington), J. J. Alvaro (Lille), V. Berg-Madsen (Uppsala), and T. V. Pegel' (Novosibirsk), and an anonymous reviewer. Thanks to all of them.

\section{References}

Ahlberg, P., and Ahlgren, J., 1996, Agnostids from the Upper Cambrian of Västergötland, Sweden: Geologiska Föreningens i Stockholm Förhandlingar 118, no. 3, pp. 129-140.

An Tai-xiang 1981. Recent progress in Cambrian and Ordovician conodont biostratigraphy of China: Geological Society of America Special Paper, v. 187 , pp. 209-225.

Brasier, M. D., 1993, Towards a carbon isotope stratigraphy of the Cambrian System: potential of the Great Basin succession: in Hallwood, E.A., and
Kidd, R. B., eds., High Resolution Stratigraphy, Geological Society Special publication, no. 70, pp. 341-350.

Brasier, M. D., Anderson, M. M., and Corfield, R. M., 1992, Oxygen and carbon isotope stratigraphy of early Cambrian carbonates in southeastern Newfoundland and England: Geological Magazine, v.129, pt. 3, pp. 265279.

Brasier, M. D., Rozanov, A. Yu., Zhuravlev, A. Yu., Corfield, R. M., and Derry, L. A., 1994, A carbon isotope reference scale for the Lower cambrian succession in Siberia: report of IGCP Project 303: Geological Magazine, v. 131, pt. 6, pp. 767-783.

Brögger, W. C., 1886, Om alderen af Olenelluszonen i Nordamerika [On the age of the Olenellus Zone in North America]: Geologiska Föreningens i Stockholm Förhandlingar, 101, v. VIII, no. 3, pp. pp. 182-213.

Chatterton, B. D. E., and Ludvigsen, R., 1998, Upper Steptoean (Upper Cambrian) trilobites from the McKay Group of Southeastern British Columbia, Canada: Journal of Paleontology, Memoir 49, 43 pp.

Cooper, R. A., 1998, Cambrian-Ordovician boundary chosen. Ordovician News, no. 15 , pp. 9-10.

Cooper, R. A., and Nowlan, G., 1999, Proposed global stratotype section and point for base of the Ordovician System: Cambrian-Ordovician Boundary Working Group Report, March 1999, 28 pp.

Fletcher, T. P., 1972, Geology and Lower to Middle Cambrian trilobite faunas of southwest Avalon, Newfoundland. Part Two. Unpubl. Ph. D. thesis, University of Cambridge, $295 \mathrm{pp}$.

Geyer, G., 1986, Mittelkambrische Mollusken aus Marokko und Spanien: Senckenbergiana lethaea, v. 67 , nos. $1 / 4$, pp. 55-118.

Geyer, G., 1990, Correlation along the Lower/Middle Cambrian boundary-a puzzling story with an elusory end?, in Repina, L. N. and Zhuravlev, A. Yu., eds., Tretij mezhdunarodnyj simpozium po kembrijskoj sisteme. Tezisy dokladov, pp. 100-102.

Geyer, G., 1993, The giant Cambrian trilobites of Morocco: Beringeria, no. 8, pp. 71-107.

Geyer, G., 1998, Intercontinental, trilobite-based correlation of the Moroccan early Middle Cambrian: Canadian Journal of Earth Sciences, v. 35, no. 4, pp. 374-401.

Geyer, G., and Palmer, A. R., 1995, Neltneriidae and Holmiidae (Trilobita) from Morocco and the problem of Early Cambrian intercontinental correlation: Journal of Paleontology, v. 69, no. 3, pp. 459-474.

Henningsmoen, G., 1957, The trilobite family Olenidae, with description of Norwegian material and remarks on the Olenid and Tremadocian Series: Norske Videnskaps-Akademi i Oslo, Mat.-Naturv. Klasse, 1957, no. 1, $303 \mathrm{pp}$.

Henningsmoen, G., 1958, The Upper Cambrian faunas of Norway; with description of non-olenid invertebrate fossils: Norsk geologisk Tidsskrift, v. 38, pp. 179-196.

Jell, P. A., and Hughes, N. C., 1997, Himalayan Cambrian trilobites: Special Papers in Palaeontology, no. 58, 113 pp.

Kirschvink, J. L., Ripperdan, R. L., and Evans, D. A., 1997, Evidence for a large-scale reorganization of Early Cambrian continental masses by inertial interchange true polar wander: Science, v. 277, 25 July 1997, pp. 541545.

Kobayashi, T., 1949, The Glyptagnostus hemera, the oldest world-instant: Japanese Journal of Geology and Geography, v. 21, pp. 1-6.

Landing, E., 1991, Upper Precambrian through Lower Cambrian of Cape Breton Island: Faunas, paleoenvironments, and stratigraphic revision: Journal of Paleontology, v. 65, no. 4, pp. 570-595.

Landing, E., 1996, Avalon: Insular continent by the latest Precambrian, in Nance, R. D. and Thompson, M. D., eds., Avalon and Related Peri-Gondwanan Terranes of the Circum-North Atlantic: Geological Society of America Special Paper 304, pp. 29-63.

Landing, E. L., Bowring, S. A., Davidek, K. L., Westrop, S. R., Geyer, G., and Heldmaier, W., 1998, Duration of the Early Cambrian: U-Pb ages of volcanic ashes from Avalon and Gondwana: Canadian Journal of Earth Sciences, v. 35, no. 4, pp. 329-338.

Lazarenko, N. P., 1966, Biostratigrafiya i nekotorye novye trilobity verkhnego kembriya Olenekskogo podnyatiya i Kharaulakhskikh gor: Uchenye Zapiyski Paleontologiya i Biostratigrafiya, no. 11, pp. 33-78.

Ludvigsen, R., and Westrop, S. R., 1985, Three new Upper Cambrian stages for North America: Geology, v. 13, pp. 139-143.

Martin, F., and Dean, W. T., 1988, Middle Cambrian acritarch and trilobite zonation at Manuels River and Random Island, eastern Newfoundland: Geological Survey of Canada, Bulletin 381, 91pp.

Miller, J. F., 1984, Cambrian and earliest Ordovician conodont evolution, biofacies, and provincialism: Geological Society of America Special Paper, no. 196, pp. 43-68. 
Moczydlowska, M., 1999, The Lower-Middle Cambrian boundary recognized by acritarchs in Baltica and at the margin of Gondwana: Bollettino della Società Paleontologica Italiana, v. 38.

Öpik, A. A., 1966, The early Upper Cambrian crisis and its correlation: Journal and Proceedings of the Royal Society of New South Wales, v. 100, pp. 9-14.

Öpik, A. A., 1967, The Ordian Stage of the Cambrian and its Australian Metadoxididae: Bureau of Mineral Resouces of Australia, Bulletin, no. 92, pp. 133-170.

Palacios, T., 1993, Acritarchs from the volcanosedimentary group Playon Beds. Lower-Upper Cambrian, Sierra Morena, southern Spain: Terra Abstracts 5, Abstracts Suppl., v. 6: pp. 3.

Palmer, A. R., 1962, Glyptagnostus and associated trilobites in the United States: United States Geological Survey, Professional Paper 374-F, 49 pp.

Palmer, A. R., 1965, Trilobites of the Late Cambrian Pterocephaliid Biomere in the Great Basin, United States: Geological Survey, Professional Paper 493, $105 \mathrm{pp}$.

Palmer, A. R., 1981, On the correlatability of the Grand Cycle Tops, in Taylor, M. E., ed., Short Papers of the Second International Symposium on the Cambrian System, Golden 1981, United States Geological Survey, Open-File Report 81-743, pp. 156-159.

Palmer, A. R., 1998a, A proposed nomenclature for stages and series for the Cambrian of Laurentia: Canadian Journal of Earth Sciences, v. 35, no. 4, pp. 323-328.

Palmer, A. R., 1998b, Why is intercontinental correlation within the Lower Cambrian so difficult? Revista Española de Paleontología, No. extr. Homenaje al Prof. Gonzalo Vidal, pp. 17-21.

Peng Shanchi, and Robison, R. A., 2000, Agnostoid biostratigraphy across the Middle-Upper Cambrian boundary in China: Journal of Paleontology, Memoir, v.38, pp.103-107.

Peng Shanchi, Zhou Zhiyi, and Lin Tianrui, 1998, Late Middle-Late Upper Cambrian chronostratigraphy of China: Fourth Field Conference of the Cambrian Stage Subdivision Working Group, International Subcommission on Cambrian Stratigraphy, Abstracts, p. 20.

Poletaeva, O. K., and Romanenko, E. V., 1970, Nekotorye trilobity srednego i pozdnego kembriya Altaya: Paleontologicheskij Zhurnal', v. 1970, no. 2: pp. 72-83

Pratt, B. R., 1992, Trilobites of the Marjuman and Steptoean stages (Upper Cambrian), Rabbitkettle Formation, southern Mackenzie Mountains, northwest Canada: Palaeontographica Canadiana, no. 9, 179 pp.

Reed, F. R. C., 1910, The Cambrian fossils of Spiti: Memoirs of the geological Survey of India, Palaeontologia Indica, ser. 15 , v. VII, Memoir 1, pp. $1-76$.

Robison, R. A., 1976, Middle Cambrian trilobite biostratigraphy of the Great Basin, in Robison, R. A. and Rowell, A. J., eds., Brigham Young University Geological Studies, no. 23, pp. 93-109.

Robison, R. A., Rosova, A. V., Rowell, A. J., and Fletcher, T. P., 1977, Cambrian boundaries and divisions: Lethaia, v. 10, no. 3, pp. 257-262.

Robison, R. A., and Rowell, A. J., 1976, Subdivisions of the Cambrian System - are traditional boundaries appropriate?: 25 th International Geological Congress, Abstracts no. 1, pp. 279-280.

Rosova, A. V. 1968, Biostratigrafiya i trilobity verkhnego kembriya i nizhnij ordovika severo-vostoka Sibirskoj platformy [Biostratigraphy and trilobites of the Upper Cambrian and Lower Ordovician of the northwestern

\footnotetext{
Dr. Gerd Geyer, Secretary of the International Subcommission on Cambrian Stratigraphy, holds an apl. professorship at the Institut für Paläontologie, Universität Würzburg, Germany. He is working on Cambrian paleontology and stratigraphy since 1980 and published around 60 monographs, papers and articles on Cambrian rocks and fossils. His Cambrian working area focuses on peri-Gondwana (Morocco, Spain, France, Israel, Jordan, Iran), but additional publications and research activities dealt with fossils from the United States, eastern Canada and China.
}

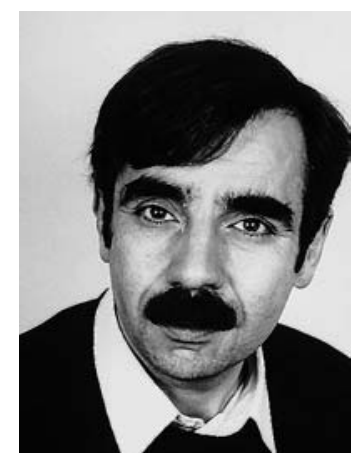

Siberian Platform]: Akademiya Nauk SSSR, Sibirsk. otdelenie, Trudy Institut Geologii i Geofiziki, no. 36, 196 pp.

Rowell, A. J., Robison, R. A., and Strickland, D. K., 1982, Aspects of Cambrian agnostoid phylogeny and chronocorrelation: Journal of Paleontology, v. 56, no. 1, pp. 161-182.

Rushton, A. W. A., 1978, Fossils from the Middle-Upper Cambrian transition in the Nuneaton district: Palaeontology, v. 21, no. 2, pp. 245-283.

Shergold, J. H., Laurie, J. R., and Sun Xiaowen, 1990, Classification and review of the trilobite order Agnostida Salter, 1864: an Australian perspective: Bureau Minereal Resources, Geology and Geophysics, Report 296, 92 pp.

Sundberg, F. A., 1994, Corynexochida and Ptychopariida (Trilobita, Arthropoda) of the Ehmaniella Biozone (Middle Cambrian), Utah and Nevada: Contributions in Science, Los Angeles County Museum of Natural History, no. 466, $137 \mathrm{pp}$.

Sundberg, F. A., and McCollum, L. B., 1997, Oryctocephalids (Corynexochida: Trilobita) of the Lower-Middle Cambrian boundary interval from California and Nevada: Journal of Paleontology, v. 71, no. 6, pp. 10651090.

Sundberg, F. A., Yuan Jin-liang, McCollum, L. B., and Zhao Yuan-long, 2000, Correlation of the Lower-Middle Cambrian boundary of South China and Laurentia: Acta Palaeontologica Sinica, v. 38, pp.103-107.

Taylor, K., and Rushton, A. W. A. (with contributions by D. E. Butler, R. Dearnley, J. R. Hawkes, P. M. Howell, and W. H. C. Ramsbottom) 1971, The pre-Westphalian geology of the Warwickshire Coalfield with a description of three boreholes in the Merevale area: Bulletin of the Geological Survey of Great Britain, v. 35, VII+152 pp.

Vanguestaine, M., and Van Looy, J., 1983, Acritarches du Cambrian Moyen de la Vallée de Tacheddirt (Haut-Atlas, maroc) dans le cadre d'une nouvelle zonation du Cambrian: Annales de la Société géologique de Belgique, v. 106, 69-85.

Walcott, Ch. D., 1891, The Fauna of the Lower Cambrian or Olenellus Zone: Tenth Annual Report of the United States Geological Survey, Part 1, pp. 509-774.

Wang Y., 1964, Handbook of index fossils of China, Hunan (South China) Region: Beijing, Science Press, 173 pp.

Westergård, A. H., 1922, Sveriges Olenidskiffer: Sveriges Geologiska Unders`kning, ser. Ca, no. 18, 205 pp. (in Swedish with English summary).

Westergård, A. H., 1946, Agnostidea of the Middle Cambrian of Sweden: Sveriges Geologiska Undersökning, Årsbok, v. 40, 140 pp.

Young, T., Martin, F., Dean, W. T., and Rushton, A. W. A., 1994, Cambrian stratigraphy of St Tudwal's Peninsula, Gwynedd, Northwest Wales Geological Magazine, v. 131, 335-360.

Yuan Jin-liang, Zhao Yuan-long, Wang Zong-zhe, Zhou Zhen, and Chen Xiao-yuan, 1997, A preliminary study on Lower-Middle Cambrian boundary and trilobite fauna at Balang, Taijian, Guizhou, South China: Acta Palaeontologica Sinica, v. 36, no. 4, pp. 494-524 (in Chinese and English).

Zhao Yuan-long, Yuan Jin-liang, Zhu, Chen Xiao-yuan, Zhou Zhen, and Zhou, 1996, The division of the Lower-Middle Cambrian boundary in China: Journal of the Guizhou Institute of Technology, v. 25, no. 4, pp. 15-20.

Zhuravlev, A. Yu., 1995, Preliminary suggestions on the global Early Cambrian zonation, in Geyer, G. and Landing, E., eds., MOROCCO '95 - the Lower-Middle Cambrian standard of western Gondwana: Beringeria Special Issue, no. 2, pp. 147-160.

Dr. John H. Shergold, a former Senior Princial Research Scientist at the Australian Geological Survey Organisation, is presently Research Associate at the Universite de Montpellier 2, France. He has 38 years experience on Cambrian-early Ordovician and Silurian trilobite taxonomy and biostratigraphy. International activity has been fostered through IGCP (particularly as co-leader of Project 156, Phosphorites) and the IUGS Subcommission on Cambrian Stratigraphy, of which he is currently Chairman.

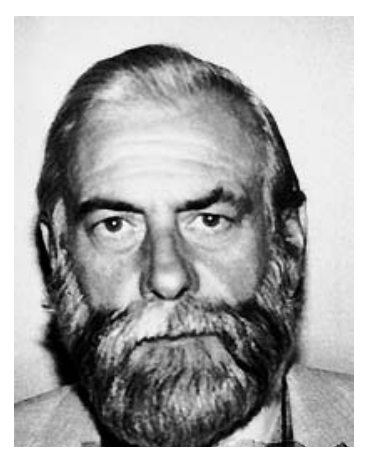

